\title{
The Mesolithic-Neolithic transition in southern Iberia
}

\author{
Miguel Cortés Sánchez a , Francisco J. Jiménez Espejo b,c,*, María D. Simón Vallejo d, Juan F. Gibaja Bao ${ }^{\text {e, }}$ \\ António Faustino Carvalho ${ }^{\mathrm{f}}$, Francisca Martinez-Ruiz ${ }^{\mathrm{b}}$, Marta Rodrigo Gamiz ${ }^{\mathrm{b}}$, José-Abel Flores ${ }^{\mathrm{g}}$, \\ Adina Paytan ${ }^{\mathrm{h}}$, José A. López Sáez ${ }^{\mathrm{i}}$, Leonor Peña-Chocarro ${ }^{\mathrm{i}}$, José S. Carrión ${ }^{\mathrm{j}}$, Arturo Morales Muñiz ${ }^{\mathrm{k}}$, \\ Eufrasia Roselló Izquierdo ${ }^{\mathrm{k}}$, José A. Riquelme Cantal ${ }^{\mathrm{b}}$, Rebecca M. Dean ${ }^{1}$, Emília Salgueiro ${ }^{\mathrm{m}, \mathrm{n}}$, \\ Rafael M. Martínez Sánchez ${ }^{\circ}$, Juan J. De la Rubia de Gracia ${ }^{\mathrm{p}}$, María C. Lozano Francisco ${ }^{\mathrm{q}}$, \\ José L. Vera Peláez ${ }^{\mathrm{q}}$, Laura Llorente Rodríguez ${ }^{\mathrm{k}}$, Nuno F. Bicho ${ }^{\mathrm{f}}$ \\ a Departamento de Prehistoria y Arqueología, Facultad de Geografía e Historia, Universidad de Sevilla, c/ María de Padilla s/n. 41004, Spain \\ b Insituto Andaluz de Ciencias de la Tierra (CSIC-UGR), Avda. de las Palmeras, 4, Armilla. 18100 Granada, Spain \\ ' Institute of Biogeosciences, Japan Agency for Marine-Earth Science and Technology (JAMSTEC), Natsushima-cho 2-15, Yokosuka 237-0061, Japan \\ d Fundación Cueva de Nerja, Crta. de Maro, s/n. 29787 Nerja, Málaga, Spain \\ e Departamento de Arqueología CSIC-IMF, Investigador Ramón y Cajal. C/ Egipciaques, 15. 08001 Barcelona, Spain \\ ${ }^{\mathrm{f}}$ FCT, Universidade do Algarve, Faculdade de Ciências Humanas e Sociais, Campus de Gambelas, 8000-117, Faro, Portugal \\ ${ }^{g}$ Departamento de Geología, Universidad de Salamanca, 37008 Salamanca, Spain \\ h Institute of Marine Sciences, Earth \& Planetary Sciences Department, University of Santa Cruz, Santa Cruz, CA 95064, USA \\ i Research group "Arqueobiología”, Centro de Ciencias Humanas y Sociales, CSIC, Albasanz, 26-28, 28037, Madrid, Spain \\ ${ }^{j}$ Departamento de Biología Vegetal (Botánica), Facultad de Biología, Universidad de Murcia, 30100, Murcia, Spain \\ k Laboratorio de Zooarqueología, Departamento de Biología, Universidad Autónoma de Madrid, 28049, Madrid, Spain \\ ${ }^{1}$ Division of Social Sciences, University of Minnesota-Morris, 600E, 4th St., Morris, Minnesota, 56267, USA \\ m Unidade de Geologia Marinha, LNEG (ex-INETI), Apart. 7586, 2720-866, Amadora, Portugal \\ n CIMAR Laboratório Associado, Rua dos Bragas, 289, 4050-123 Porto, Portugal \\ - Área de Prehistoria, Facultad de Filosofía y Letras, Universidad de Córdoba, Plaza Cardenal Salazar, s/n. 14071, Córdoba, Spain \\ p Archivo Municipal de Mijas, Avda. Virgen de la Peña, 2. 29650 Mijas, Málaga, Spain \\ ${ }^{q}$ Museo Municipal Paleontológico de Estepona, Matías Prats, s/n. 29680, Estepona, Málaga, Spain
}

\section{A R T I C L E I N F O}

\section{Article history:}

Received 3 March 2011

Available online 20 January 2012

\section{Keywords:}

Abrupt climate change

Mesolithic-Neolithic transition

South Iberia

Holocene

Migration

Hunter-fisher-gatherers

Paleoceanography

\begin{abstract}
A B S T R A C T
New data and a review of historiographic information from Neolithic sites of the Malaga and Algarve coasts (southern Iberian Peninsula) and from the Maghreb (North Africa) reveal the existence of a Neolithic settlement at least from $7.5 \mathrm{cal} \mathrm{ka} \mathrm{BP.} \mathrm{The} \mathrm{agricultural} \mathrm{and} \mathrm{pastoralist} \mathrm{food} \mathrm{producing} \mathrm{economy} \mathrm{of} \mathrm{that} \mathrm{population}$ rapidly replaced the coastal economies of the Mesolithic populations. The timing of this population and economic turnover coincided with major changes in the continental and marine ecosystems, including upwelling intensity, sea-level changes and increased aridity in the Sahara and along the Iberian coast. These changes likely impacted the subsistence strategies of the Mesolithic populations along the Iberian seascapes and resulted in abandonments manifested as sedimentary hiatuses in some areas during the Mesolithic-Neolithic transition. The rapid expansion and area of dispersal of the early Neolithic traits suggest the use of marine technology. Different evidences for a Maghrebian origin for the first colonists have been summarized. The recognition of an early North-African Neolithic influence in Southern Iberia and the Maghreb is vital for understanding the appearance and development of the Neolithic in Western Europe. Our review suggests links between climate change, resource allocation, and population turnover.
\end{abstract}

(c) 2011 University of Washington. Published by Elsevier Inc. All rights reserved.

\footnotetext{
* Corresponding author.

E-mail addresses: mcortes@us.es (M. Cortés Sánchez), fjjspejo@ugr.es (F.J. Jiménez Espejo), mm.cosi@terra.es (M.D. Simón Vallejo), jfgibaja@imf.csic.es (J.F. Gibaja Bao),

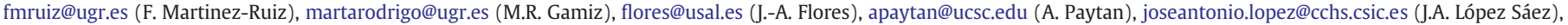
leonor.chocarro@cchs.csic.es (L. Peña-Chocarro), carrion@um.es (J.S. Carrión), arturo.morales@uam.es (A. Morales Muñiz), eufrasia.rosello@uam.es (E. Roselló Izquierdo), rdean@umn.edu (R.M. Dean), emilia.salgueiro@lneg.pt (E. Salgueiro), martsancho@hotmail.com (R.M. Martínez Sánchez), jjdelarubia@mijas.es (J.J. De la Rubia de Gracia), mclozano63@hotmail.com (M.C. Lozano Francisco), joselverapelaez@gmail.com (J.L. Vera Peláez), la_llorente@yahoo.es (L.L. Rodríguez), nbicho@ualg.pt (N.F. Bicho).
} 